\title{
Successful telecollaboration exchanges in primary and secondary education: what are the challenges?
}

\author{
Kristi Jauregi ${ }^{1}$ and Sabela Melchor-Couto ${ }^{2}$
}

\begin{abstract}
The TeCoLa project promotes telecollaboration to foster meaningful foreign language learning particularly in secondary schools throughout Europe. In 2018, a number of pilot experiences are being conducted. This paper focusses on one of these pilot experiences, where learners from a Dutch secondary school and a Spanish primary school telecollaborated in Spanish and English by carrying out four tasks (creation of vlogs) asynchronously and sharing them in their group's Padlet wall. Different sources of data were gathered (recordings, surveys, and interviews) in order to be able to disentangle the factors that might play a role in successful telecollaboration exchanges and language learning experiences. Overall learners seemed to enjoy the experience, but the Spanish participants found the exchanges much more meaningful than the Dutch ones. This might well be related to the autonomy given to the students, who might have needed further guidance to benefit fully from the exchange.
\end{abstract}

Keywords: telecollaboration, motivation, anxiety, primary/secondary/pre-university education, vlogs.

\section{Introduction}

The Erasmus+ project TeCoLa (2016-2019) promotes telecollaboration (Guth \& Helm, 2010) to foster meaningful foreign language learning, particularly in secondary schools throughout Europe, while training and coaching teachers. Special attention is given to task development that facilitates authentic communication in the foreign language, intercultural experience, awareness raising, and competence

1. Utrecht University, Utrecht, the Netherlands; k.jauregi@uu.nl

2. University of Roehampton, London, United Kingdom; s.melchor-couto@roehampton.ac.uk

How to cite this article: Jauregi, K., \& Melchor-Couto, S. (2018). Successful telecollaboration exchanges in primary and secondary education: what are the challenges? In P. Taalas, J. Jalkanen, L. Bradley \& S. Thouësny (Eds), Future-proof CALL: language learning as exploration and encounters - short papers from EUROCALL 2018 (pp. 112-117). Research-publishing.net. https://doi.org/10.14705/rpnet.2018.26.822 
development in the Target Language (TL), taking into account the specific school contexts and tool affordances.

Several pilot experiences are being carried out in different TLs, making use of different technologies to engage young learners in telecollaboration practices. The TeCoLa team is interested in knowing which factors contribute to successful telecollaboration exchanges implemented at pre-university educational level. In this paper we focus on a pilot experience carried out among learners from secondary and primary schools who created cultural vlogs to inform their peers abroad about cultural issues in their country/region. These vlogs were shared via the online bulletin board Padlet.

Since very little is known about the factors that play a role in telecollaborative exchanges among young teen learners, our study focussed on the following: (1) the effects such exchanges have on these learners' motivations, and (2) the experiences they engender in learners and teachers who participate in them.

\section{Method}

\subsection{Context}

TeCoLa views diversity as a socially meaningful concept in education that should strategically lead towards understanding and valuing diversity as a prerequisite for an inclusive society. The present pilot consisted of a telecollaboration project between two schools at different educational levels (primary and secondary) in two different countries (Spain and the Netherlands).

Two TeCoLa coaches assisted the school teachers and monitored the experience. Together they analysed and compared the specific school contexts and curriculums. Because of technological limitations on the part of one school, it was decided that the telecollaborative exchange should be asynchronous. Using either their own smartphones or ones provided by their teachers, groups of learners from the two schools then created vlogs in their TL, which they shared with their partner groups abroad through a Padlet wall.

The participants of this exchange, which was carried out between April and June 2018, were 17 learners of Spanish from a Dutch bilingual secondary school (ages 13-14) and 22 learners of English from a Spanish primary school (ages 11-12). 
The Dutch and the Spanish learners had an A2 proficiency level in their TL. A total of five groups were created in each school and subsequently paired with parallel groups in the other country. Separate Padlet environments were created for those international groups engaged in telecollaboration activities. The participants uploaded their group vlogs to their own shared Padlet and viewed and listened to the ones their partners abroad had recorded (see Figure 1).

Figure 1. Screenshot Padlet wall

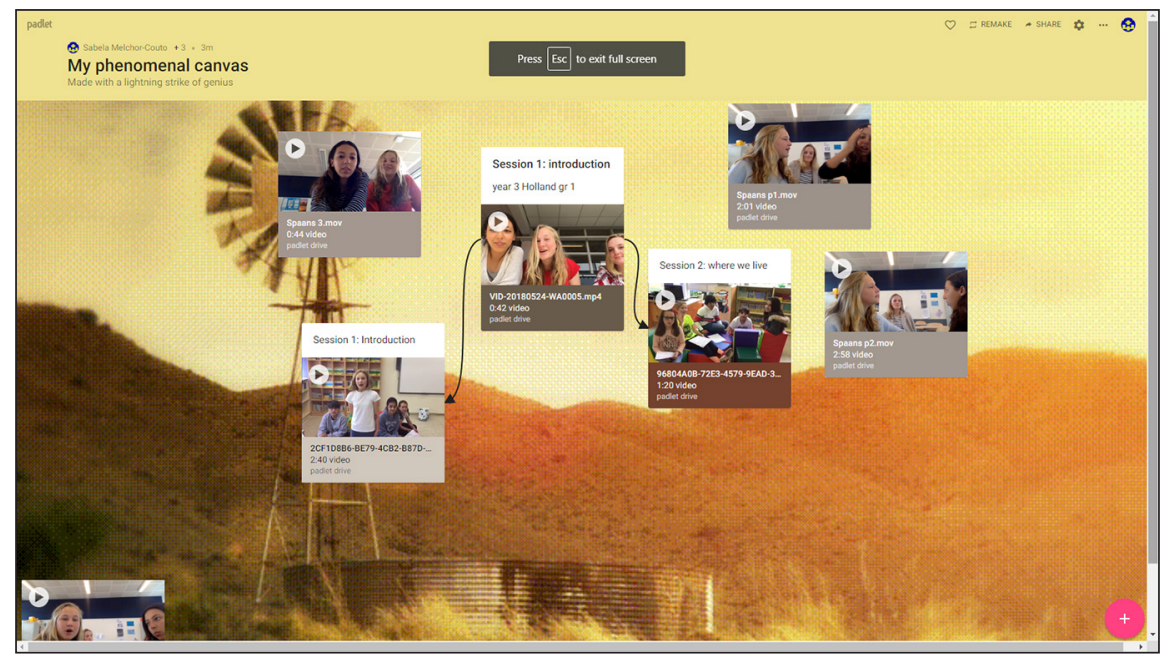

Four tasks (T1-T4) were created attending to the intercultural focus oriented educational programme that learners were following at both schools. In T1, learners introduced themselves and their school. In T2, they provided general information about their country/region. In T3, they informed their peers about what to see, where to go, and what to do when visiting their country/region. Finally, in T4, learners provided intercultural information about their region/country (how people live, what a regular day is like, how they celebrate their birthday, etc.).

Tasks 1, 2, and 4 were carried out in the TL (Spanish for the Dutch learners and English for the Spanish learners). The topic of T3 was more complex and it was decided that it would be carried out in Spanish for the Spanish learners and in English for the bilingual Dutch learners. This strategy enabled students to develop a range of language skills, namely oral expression and listening comprehension, both in their TL and mother tongue/proficient foreign language. 


\subsection{Instruments}

The participants were required to complete a survey after every task consisting of ten five-point Likert scale items. All surveys were provided in the students' mother tongue and included closed items related to self-efficacy, anxiety, attitudes towards communication, technology, and the task (based on Jauregi, de Graaff, van den Bergh, \& Kriz, 2012 and Jauregi \& Melchor-Couto, 2017). The first survey included 15 additional open and closed items to gather background and learning preferences information. In the last one, students were also asked to rate the project.

The link to the Dutch surveys was distributed by email by the teacher after completion of each task. The surveys were printed out for the younger Spanish learners, who filled them in during their English classes. The results were then manually uploaded to the digital form. The Spanish learners' survey completion rate was considerably higher as compared to that of the Dutch learners, who responded to the survey only in certain sessions - the first survey was completed by all the participants (17), followed by ten, nine, and five respondents in subsequent sessions.

Four Spanish and three Dutch learners and their teachers were individually interviewed in their mother tongue at the end of the project in order to get a more in-depth view of how teachers and learners experienced the telecollaboration project.

\section{Results}

\subsection{Motivational factors}

The affective scores entered by Dutch and Spanish learners on the first and last sessions were compared (see Table 1). Learners' attitudes towards communicating in the TL were found to differ greatly among both groups, the Spanish learners valuing it with higher scores than the Dutch ones (Items 1 and 2). The comparison of T1 and T4 scores reveals a marked increase in the perceived usefulness of the exchange reported by the Spanish pupils, which is in contrast with the lower scores given in T4 by the Dutch learners. However, only five Dutch students responded to the survey circulated after T4 and therefore this value must be interpreted with caution. Self-efficacy values (Items 4 and 5) were similar for both groups, although 
a slight increase is observed amongst the Spanish learners on completion of the exchange regarding their perceived ability to express themselves in the TL (Item 5). Finally, both groups reported low levels of anxiety (Items 6 and 9), although the scores provided by the Dutch learners were slightly higher in both items.

Table 1. Affective factors

\begin{tabular}{|c|c|c|c|c|c|c|c|c|c|}
\hline \multirow{3}{*}{\multicolumn{2}{|c|}{ Items }} & \multicolumn{4}{|c|}{ Dutch pupils } & \multicolumn{4}{|c|}{ Spanish pupils } \\
\hline & & \multicolumn{2}{|c|}{ T1 } & \multicolumn{2}{|l|}{ T4 } & \multicolumn{2}{|c|}{ T1 } & \multicolumn{2}{|l|}{ T4 } \\
\hline & & Mean & SD & Mean & SD & Mean & SD & Mean & SD \\
\hline \multirow{2}{*}{ 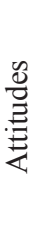 } & $\begin{array}{l}\text { 1. I learn a lot by using } \\
\text { the TL to communicate } \\
\text { with learners abroad }\end{array}$ & 3.2 & 0.8 & 2.0 & 1.2 & 3.9 & 1.3 & 4.3 & 0.8 \\
\hline & $\begin{array}{l}\text { 2. I like to use the TL } \\
\text { to communicate with } \\
\text { learners abroad }\end{array}$ & 3.4 & 1.0 & 3.4 & 1.1 & 4.0 & 1.1 & 4.0 & 1.0 \\
\hline \multirow{2}{*}{ 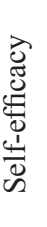 } & $\begin{array}{l}\text { 4. I think that my TL } \\
\text { competence is sufficient } \\
\text { to communicate with } \\
\text { learners abroad }\end{array}$ & 3.1 & 1.1 & 3.2 & 0.8 & 3.0 & 0.8 & 3.2 & 1.2 \\
\hline & $\begin{array}{l}\text { 5. I express myself } \\
\text { well in the TL }\end{array}$ & 3.2 & 0.8 & 3.2 & 0.4 & 2.8 & 1.0 & 3.2 & 1.0 \\
\hline \multirow{2}{*}{ : } & $\begin{array}{l}\text { 6. I'm afraid that my } \\
\text { classmates will laugh at } \\
\text { me when I use the TL }\end{array}$ & 2.5 & 1.4 & 2.4 & 1.5 & 2.0 & 1.0 & 1.7 & 1.0 \\
\hline & $\begin{array}{l}\text { 9. I get nervous when } \\
\text { I have to use technology } \\
\text { to practise the TL }\end{array}$ & 2.4 & 1.2 & 2.2 & 1.3 & 1.7 & 0.7 & 1.9 & 1.2 \\
\hline
\end{tabular}

\subsection{Teachers' and learners' experience}

Teachers' behaviour towards the project differed greatly. The Spanish teacher integrated the project in his classes and coached the learners during the whole process. For the Dutch teacher, the project was an add-on activity. The learners were supposed to work on the videos outside the classroom or during the last 10 minutes of the class. This teacher found the 'autonomy' with which learners had worked on the tasks as very relevant and meaningful. However, this 'autonomy' might have been experienced as 'lack of guidance' (learners received no feedback and not enough time to work on the tasks), as reported by the pupils interviewed. Most learners were positive about the project but especially the Spanish ones rated the telecollaborative experience with very high scores (Dutch learners' mean value: 3.8; Spanish: 4.6). The difference in age and educational school level did not seem to constitute a problem in the exchanges at all, as reported by six of 
the seven interviewed learners. In spite of the different approaches, both teachers were positive about the project as a whole and manifested their wish to repeat the experience next year by integrating it in the curriculum. Even the Dutch teacher seemed to realise that more guidance and monitoring was necessary to contribute to the meaningfulness of the activity for the learners.

\section{Conclusions}

This paper shows that telecollaboration projects across levels (secondary and primary education) can be valuable for learners, particularly if teachers are actively engaged in guiding them while respecting their autonomy. Further research will be required to analyse in more detail student attitudes regarding issues such as age difference, amongst others.

\section{Acknowledgements}

We would like to thank the teachers and students who participated in this exchange for their time and dedication in making this exchange a reality.

\section{References}

Guth, S., \& Helm, F. (Eds). (2010). Telecollaboration 2.0. Language, literacies and intercultural learning in the 21st century. Peterlang Publishers. https://doi.org/10.3726/978-3-0351-0013-6 Jauregi, K., \& Melchor-Couto, S. (2017). Motivational factors in telecollaborative exchanges among teenagers. In K. Borthwick, L. Bradley \& S. Thouësny (Eds), CALL in a climate of change: adapting to turbulent global conditions - short papers from EUROCALL 2017 (pp. 157-162). Research-publishing.net. https://doi.org/10.14705/rpnet.2017.eurocall2017.706

Jauregi, K., de Graaff, R., van den Bergh, H. \& Kriz, M. (2012). Native non-native speaker interactions through video-web communication, a clue for enhancing motivation. Computer Assisted Language Learning Journal, 25(1), 1-19. 


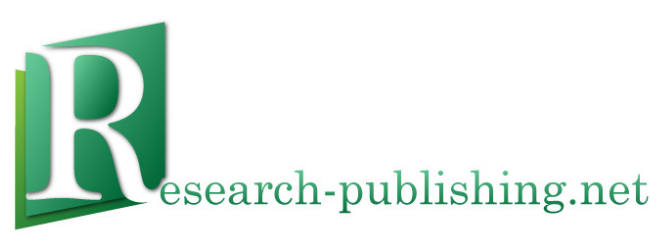

Published by Research-publishing.net, a not-for-profit association Contact: info@research-publishing.net

(C) 2018 by Editors (collective work)

(C) 2018 by Authors (individual work)

Future-proof CALL: language learning as exploration and encounters - short papers from EUROCALL 2018 Edited by Peppi Taalas, Juha Jalkanen, Linda Bradley, and Sylvie Thouësny

\section{Publication date: 2018/12/08}

Rights: the whole volume is published under the Attribution-NonCommercial-NoDerivatives International (CC BYNC-ND) licence; individual articles may have a different licence. Under the CC BY-NC-ND licence, the volume is freely available online (https://doi.org/10.14705/rpnet.2018.26.9782490057221) for anybody to read, download, copy, and redistribute provided that the author(s), editorial team, and publisher are properly cited. Commercial use and derivative works are, however, not permitted.

Disclaimer: Research-publishing.net does not take any responsibility for the content of the pages written by the authors of this book. The authors have recognised that the work described was not published before, or that it was not under consideration for publication elsewhere. While the information in this book is believed to be true and accurate on the date of its going to press, neither the editorial team nor the publisher can accept any legal responsibility for any errors or omissions. The publisher makes no warranty, expressed or implied, with respect to the material contained herein. While Researchpublishing.net is committed to publishing works of integrity, the words are the authors' alone.

Trademark notice: product or corporate names may be trademarks or registered trademarks, and are used only for identification and explanation without intent to infringe.

Copyrighted material: every effort has been made by the editorial team to trace copyright holders and to obtain their permission for the use of copyrighted material in this book. In the event of errors or omissions, please notify the publisher of any corrections that will need to be incorporated in future editions of this book.

Typeset by Research-publishing.net

Cover theme by (C) 2018 Antti Myöhänen (antti.myohanen@gmail.com)

Cover layout by (C) 2018 Raphaël Savina (raphael@savina.net)

Drawings by (C) 2018 Linda Saukko-Rauta (linda@redanredan.fi)

ISBN13: 978-2-490057-22-1 (Ebook, PDF, colour)

ISBN13: 978-2-490057-23-8 (Ebook, EPUB, colour)

ISBN13: 978-2-490057-21-4 (Paperback - Print on demand, black and white)

Print on demand technology is a high-quality, innovative and ecological printing method; with which the book is never 'out of stock' or 'out of print'.

British Library Cataloguing-in-Publication Data.

A cataloguing record for this book is available from the British Library.

Legal deposit, UK: British Library.

Legal deposit, France: Bibliothèque Nationale de France - Dépôt légal: Décembre 2018. 